\title{
Physicochemical properties and antioxidant capacity of propolis of stingless bees (Meliponinae) and Apis from two regions of Tocantins, Brazil
}

\author{
Karuane Saturnino da Silva ARAÚJO ${ }^{1 *}$; Joaquim Francisco dos Santos JÚNIOR ${ }^{2}$; Marcello Otake SATO ${ }^{1,3}$; \\ Fernanda Dias Bartolomeu Abadio FINCO²; Ilsamar Mendes SOARES ${ }^{5}$; Robson dos Santos BARBOSA ${ }^{4}$; Tarso \\ da Costa ALVIM ${ }^{4}$; Sérgio Donizeti ASCÊNCIO ${ }^{3,5}$; Sandra Maria Botelho MARIANO ${ }^{1,3}$ \\ 1 Universidade Federal do Tocantins, Programa de Pós-Graduação em Ciências da Saúde. Avenida NS 15, Quadra 109 Norte, Campus Universitário de Palmas, \\ Palmas - TO, CEP 77001-090, Brasil. \\ 2 Universidade Federal do Tocantins, Laboratório de Segurança Alimentar e Nutricional. Avenida NS 15, Quadra 109 Norte, Campus Universitário de Palmas, \\ Palmas - TO, CEP 77001-090, Brasil. \\ 3 Universidade Federal do Tocantins, Curso de Medicina. Avenida NS 15, Quadra 109 Norte, Campus Universitário de Palmas, Palmas - T0, CEP 77001-090, Brasil. \\ ${ }^{4}$ Universidade Federal do Tocantins, Laboratório de Instrumentação Científica. Mestrados em Agroenergia e Ciência de Alimentos. Avenida NS 15, Quadra 109 Norte, \\ Campus Universitário de Palmas, Palmas - T0, CEP 77001-090, Brasil. \\ ${ }^{5}$ Universidade Federal do Tocantins, Laboratório de Pesquisa em Produtos Naturais. Avenida NS 15, Quadra 109 Norte, Campus Universitário de Palmas, \\ Palmas - TO, CEP 77001-090, Brasil. \\ Corresponding author: karuane@gmail.com.
}

\begin{abstract}
The composition of propolis depends on time, vegetation and the location of the collection area. The objective of this study was to determine the physicochemical characteristics, the concentration of phenol compounds and the antioxidant capacity of propolis of native stingless bees (Meliponinae) and Apis from the State of Tocantins. Extraction with 80\% ethanol (v/v) was performed in order to obtain the extracts. Parameters examined were: propolis mass loss by desiccation at $105^{\circ} \mathrm{C}$, ashes, wax concentration and $\mathrm{pH}$. Furthermore, the propolis antioxidant activity was measured, as well as the total concentration of phenol compounds. The extracts were also analyzed by high performance liquid chromatography. The total concentration of phenol compounds varied between 121.78 and $631.29\left(\mathrm{mg} \mathrm{GAE} \mathrm{g}^{-1}\right)$. The antioxidant activity expressed by the value of $\mathrm{CE}_{50}$ varied between 29.81 and $845.38 \mu \mathrm{g} \mathrm{mL}^{-1}$. High performance liquid chromatography analysis allowed us to infer the existence of phenol compounds. The results indicated that the studied propolis samples constitute good sources of natural antioxidants. The variety of phenol compounds identified in this study, and the diverse biological functions reported in literature for these compounds indicated that this stingless bee propolis (Meliponinae) and Apis has a high pharmacological potential.
\end{abstract}

KEYWORDS: Propolis, antioxidant, phenol compounds.

\section{Propriedades físico-químicas e capacidade antioxidante de própolis de abelhas sem ferrão (Meliponinae) e Apis de duas regiões do Tocantins, Brasil}

\begin{abstract}
RESUMO
A composição da própolis depende do tempo, da vegetaçáo e a localizaçáo da área de coleta. Este estudo teve como objetivo determinar as características físicas e químicas, o teor de compostos fenólicos e capacidade antioxidante da própolis de abelhas nativas sem ferrão (Meliponinae) e Apis do Estado do Tocantins. Para a obtenção dos extratos empregou-se extração com etanol $80 \%(\mathrm{v} / \mathrm{v})$. Os parâmetros analisados foram: perda de peso por dessecação a $105^{\circ} \mathrm{C}$, cinzas, Teor de cera e $\mathrm{pH}$. Além dessas foi mensurada a atividade antioxidante e o teor de compostos fenólicos totais. Adicionalmente os extratos de própolis foram também analisados por cromatografia líquida de alta eficiência. O teor de compostos fenólicos totais variou entre 121,78 e $631,29\left(\mathrm{mg} \mathrm{GAE} \mathrm{g}^{-1}\right)$. A atividade antioxidante expressa pelo valor de $\mathrm{CE}_{50}$ variou entre 29,81 e 845,38 $\mu \mathrm{g} \mathrm{mL} \mathrm{mL}^{-1}$. As análises por cromatografia líquida de alta eficiência permitiram inferir a existência de compostos fenólicos. Os resultados indicaram que as amostras de própolis estudadas constituem boas fontes de antioxidantes naturais. A variedade de compostos fenólicos identificada neste estudo, e as diversas funçôes biológicas relatadas na literatura para estes compostos, indicaram que a própolis de abelhas sem ferrão (Meliponinae) e Apis tem um grande potencial farmacológico.
\end{abstract}

PALAVRAS-CHAVE: Própolis, antioxidante, compostos fenólicos. 


\section{INTRODUCTION}

Propolis is a generic designation given to products with viscous consistencies elaborated by Apis mellifera bees from plant parts, salivary secretions and wax produced by the bees themselves. In this way, the composition of propolis is a reflex of vegetable flora, which serves bees (Somnez et al. 2005; Cabral et al. 2012). Geopropolis is produced by Meliponinae bees, which collect resinous material from plants and bring to the beehive, mix with wax and clay or soil (Dutra et al. 2008).

Among bee products, propolis has been the subject of pharmacological studies due to its antimicrobial (Simóes et al. 2008), anti-inflammatory (Franchin et al. 2013), antioxidant properties (Perchyonok et al. 2013), among others. This biological potential is due to a synergy that occurs between the many constituents. Propolis is an important therapeutic alternative, from the economic point of view, and pharmacologically efficient, easily obtained, presenting pharmaceutical properties (Alencar et al. 2005).

Recent studies described the benefits of antioxidant substances for health, due to its effects on disease prevention such as cancer, cardiovascular diseases and aging. Phenol compounds are antioxidant substances frequently found on propolis. Among the most studied is gallic acid (Prado 2009). The use of substances with antioxidant capacity can be of great relevance in the prevention and treatment of diseases related to the increase of oxidative stress (Marquele et al. 2006; Lima et al. 2009; Restivo et al. 2014).

Stingless bees, also known as native bees, social and stingless, occupy most tropical regions in the planet, especially South America. In Brazil, there are more than 400 species of native bees, which are responsible for $90 \%$ of pollination of native vegetables (Dutra et al. 2008).

Due to the socio-economic importance for small farmers and the environmental preservation provided by the creation of native bees, indicate the relevance of this matter and initiate, in a certain way, the study of therapeutic properties of propolis produced by Melipona scutellaris L., Melipona fasciculata S. e Apis mellifera L. bees in the State of Tocantins.

The objective of this study was to determine the physicochemical characteristics, the concentration of phenol compounds and the antioxidant capacity of propolis of stingless native bees (Meliponinae) and Apis from the regions of Novo Acordo and Santa Maria of Tocantins, North of Brazil (State of Tocantins).

\section{MATERIALS AND METHODS}

\section{Sampling}

Samples of propolis were collected, produced by $M$. scutellaris bees from the city of Novo Acordo, as well as samples of propolis produced by $M$. fasciculata bees from the city of Santa Maria of Tocantins, besides the samples of propolis produced by $A$. mellifera bees from both cities, between January and August of 2014. The samples were collected directly from the apiaries, conditioned in sterile bottles, protected from light and forwarded to the Food Security and Nutritional Laboratories, Research on Natural Products Laboratory and Scientific Instrumentation Laboratory from the Federal University of Tocantins - UFT, for the conduction of the analyzes.

\section{Obtaining the extracts}

In order to obtain the extracts, the methodology proposed by Park et al. (1998) was used with some modifications. Samples of $4 \mathrm{~g}$ of propolis were grinded, homogenized and submitted to extraction with $50 \mathrm{~mL}$ of $80 \%$ ethanol $(\mathrm{v} / \mathrm{v})$, at a temperature of $70{ }^{\circ} \mathrm{C}$, in water-bath (CE-160, CIENLAB, Campinas, Brazil), under constant agitation during 30 minutes. The samples were then centrifuged (80-2B, CentriBio, Campinas, Brazil) at $3500 \mathrm{rpm}$ for 10 minutes; the residue was re-extracted twice using the same concentration of ethanol. The supernatants were combined, concentrated in rotary evaporator (Q344B2, QUIMIS, Diadema, Brazil) and dried in a exhaustion hood. The dry extract was stored in a desiccator until the analyzes were performed.

\section{Physicochemical analyzes specifications}

For the analysis of loss by desiccation $105^{\circ} \mathrm{C}, 3 \mathrm{~g}$ of gross propolis, previously pulverized, were weighed and taken to the stove (Q317M-12, QUIMIS, Diadema, Brazil) at 105 ${ }^{\circ} \mathrm{C}$, for two hours, repeating this process until a constant weight was obtained. The result was calculated by the rate between the volatized material mass and the initial propolis mass, expressed in percentage (European Pharmacopoeia, 2002). In the concentration of ashes analysis, the samples previously dried and weighed were heated in a muffle (BT 201/RP, Biothec, Piracicaba, Brazil) at $600^{\circ} \mathrm{C}$, for 7 hours. The concentration of ashes was calculated by the rate between the mass of the ashes and the initial propolis mass, expressed in percentage (European Pharmacopoeia 2002). In order to determine the concentration of wax, $1.0 \mathrm{~g}$ of propolis was weighed, placed in glass bottles with lids and submitted to extraction with three fractions of $10 \mathrm{~mL}$ of petroleum ether, under heating in boiling water-bath (b.w.b).

In order to determine the concentration of wax, $1.0 \mathrm{~g}$ of propolis was weighed, placed in glass bottles with lids and submitted to extraction with three fractions of $10 \mathrm{~mL}$ of petroleum ether, under heating in boiling water-bath (b.w.b). The apolar fraction was disregarded and the remaining propolis were dried in b.w.b., cooled and submitted to new weighing. The results are expressed in percentage $(\%, \mathrm{p} / \mathrm{p})$ (Longhini et al. 2007). The $\mathrm{pH}$, using a digital pHmeter 
(MPA-210, TECNOPON, Campinas, Brazil), and density determinations were conducted based on the method described by AOAC (2005). The analyzes results of the physicochemical requirements were expressed by the average and the standard deviation, and compared to the values suggested by the Normative Ruling $\mathrm{n}^{\circ} 3$ of the Ministry of Agriculture and Supply (BRAZIL 2001).

\section{Total phenol dosage}

The quantification of total phenol compounds was conducted by the Folin-Ciocalteu method, as described by Amorim et al. (2008), using gallic acid as standard. Methanol solutions were prepared from the extract at $1 \mathrm{mg} \mathrm{mL}^{-1}$, and from the standard at $0.1 \mathrm{mg} \mathrm{mL}^{-1}$. Aliquots from the extract solutions $(0.2 \mathrm{~mL})$ or from the standard (0.01 to $0.2 \mathrm{~mL}$ ) were mixed with an aqueous solutions of the Folin-Ciocalteu reactant $(0.5 \mathrm{~mL}$ to $10 \%, \mathrm{v} / \mathrm{v})$, sodium carbonate $(1 \mathrm{~mL}$ at $75 \%, \mathrm{p} / \mathrm{v}$ ), the volume for $10 \mathrm{~mL}$ with distilled water was measured, carefully agitated and maintained for 30 minutes protected from light. The absorbance was measured at 760 $\mathrm{nm}$, in spectophotometry UV-VIS Biochrom Biowave II+ equipped with $1 \mathrm{~cm}$ quartz cells in optic path, calibrated with all the reactants from the reaction complex, except the extract. Total phenol concentrations were determined by interoplations of the absorbances of the samples against a calibration curve elaborated with different concentrations of the gallic acid standard, expressed as miligrams gallic acid equivalents per gram dry extract $\left(\mathrm{mg} \mathrm{GAE} \mathrm{g}^{-1}\right)$. All the experiments were conducted in triplicate.

\section{Evaluation of antioxidant activity}

The antioxidant capacity was measured by the DPPH method, following the descriptions in Peixoto-Sobrinho et al. (2011) with modifications, having rutin and ascorbic acid standards as positive controls. In triplicates, $1 \mathrm{~mL}$ of different standard or extract concentrations $\left(50-400 \mu \mathrm{g} \mathrm{mL}^{-1}\right)$ were added to a methanol DPPH solution ( $3 \mathrm{~mL}$ to $40 \mu \mathrm{g} \mathrm{mL}^{-1}$ ). A blank was elaborated by replacing DPPH for methanol in the reaction medium. The reaction complex and the blank were agitated and maintained for 30 minutes, protected from light, and the absorbances measures at $517 \mathrm{~nm}$ in spectropgotometry calibrated with methanol. The absorbance of the DPPH solution at $40 \mu \mathrm{g} \mathrm{mL}^{-1}$ was also measured and used as a negative control. Removal of free radicals activity or antioxidant activity was expressed as a porcentage of inhibition determined by the equation:

$$
\% \mathrm{AA}=\mathrm{ABS}_{\mathrm{cn}}-\left(\mathrm{ABS}_{\text {sample }}-\mathrm{ABS}_{\text {blank }}\right) / \mathrm{ABS}_{\mathrm{cn}} \times 100
$$

where $\% \mathrm{AA}$ is the porcentage of antioxidant activity; $\mathrm{ABS}_{\mathrm{cn}}$, the absorbance of the negative control; $\mathrm{ABS}_{\text {sample }}$, the absorbance of the sample; $A B S_{\text {blank }^{\prime}}$, the absorbance of the blank.
Using the calibration curves obtained by the plotting of different concentrtions in relation to \% AAs, the efficient concentration was calculated, the quantity of sample needed to decrease the initial concentration of DPPH in $50 \%\left(\mathrm{CE}_{50}\right)$, which was expressed in $\mu \mathrm{g} \mathrm{mL}^{-1}$.

\section{Analysis by Thin Layer Chromatography (TLC)}

Preparative thin layer chromatography was performed, using ellagic acid, gallic acid, catechin, kaempferol, luteolin, morin, naringin, rutin as reference substances. Silica gel plates, $0.20 \mathrm{~mm}$ kieselgel 60 ALUGRAM $^{\circ}$ SIL G. (MACHEREY-NAGEL), were used as stationary phase, and as mobile phase: Benzene: ethyl acetate: formic acid: methanol $(60 / 30 / 10 / 3,5 \mathrm{v} / \mathrm{v})$ and developers: NP/PEG 2-Aminoethyl diphenylborinate (1\% in methanol) and polyethylene glycol (5\% in ethanol). The visualization of stains for the determination of retention factors (Rf) occured in UV chamber (SL-204, SOLAB, Piracicaba, Brazil) at $365 \mathrm{~nm}$.

\section{Analysis by High Performance Liquid Chromatography (HPLC)}

High performance liquid chromatography (HPLC) was developed in a Chromatograph (LC-10 Avp series, Shimadzu, Kyoto, Japan), equipped with a pump (LC10AD), gas relief (DGU-14A), UV-VIS detector (SPD10A), column oven (CTO-10A), Rheodyne manual injector $(20 \mu \mathrm{L}$ loop $)$ and CLASS integrator (LC-10A). The separation was developed in a gradient system, using a Phenosphere reverse phase column $5 \mu$ ODS (2) $80^{\mathrm{a}}$ $(250 \times 4.6 \mathrm{~mm})$ and a Phenomenex C18 pre-column ( $4 \mathrm{x}$ $3,0 \mathrm{~mm}$ ), completed with a material similar to the main column. The mobile phase consisted of, A: $0.2 \%$ of formic acid in $\mathrm{H}_{2} \mathrm{O}$ and $\mathrm{B}: 0.2 \%$ of formic acid in $\mathrm{MetOH}$ and C: methanol/water/acetic acid (1:18:1), flow rate at $1 \mathrm{~mL}$ $\mathrm{min}^{-1}$, temperature at $40{ }^{\circ} \mathrm{C}$, UV detection at $280 \mathrm{~nm}$. The programming of the elution gradient was: $0-0.01,1 \%$ C; $0.01-1,50 \%$ C; $1-2.5,100 \%$ C; $2.5-3,100 \%$ C; 3-5, $100 \%$ C; 5-6, 100\% C; 6-7, 100\% C; 7-8, 100\% C; 8-9, 1\% C; 9-9.5, 0\% C; 9.5-10, 0\% B; 10-11, 1\% B; $11-12,5 \%$ B; $12-18,25 \%$ B; $18-20,60 \%$ B; $20-25,70 \%$ B; $25-30,75 \%$ B; 30-35, $80 \%$ B; 35-40, 90\% B; 40-45, $95 \%$ B; $45-50,100 \%$ B; 50-60, 100\% B. The compounds were identified by comparing the retention time of the samples and the authentic standards, such as ellagic acid, gallic acid, catechin, gallocatechin, hesperidin, kaempferol, luteolin, myricetin, morin, naringin, naringenin, quercetin, rutin (Sigma). Before being injected into the equipment, the extracts were degreased by partition with $\mathrm{n}$-hexane, the standards were dissolved in methanol. The extracts and the standards were dissolved in methanol and filtered in Millipore membrane (0.22 $\mu \mathrm{m}$ of pore diameter). 


\section{Statistical analysis}

All analyzes were conducted in triplicate. The statistical analyzes used comprised average and standard deviation. Afterwards, the results were submitted to ANOVA analysis and Post-hoc Fischer $(\mathrm{p}<0.05)$. The correlation analysis by Pearson coefficient was performed according to FigueiredoFilho and Silva-Júnior (2009). The calculations were conducted using the BIOESTAT $5.3^{\circ}$ software.

\section{RESULTS}

It was observed that all propolis produced by $M$. fasciculata and $M$. scutellaris bees produced propolis with sandy physical aspects, while propolis produced by $A$. mellifera bees presented a resinous aspect. The physicochemical characteristics of the propolis evaluated are presented in Table 1.

The correlation equation and the linearity coefficient obtained for the calibration curve used to quantify total phenols were, respectively, $y=0.0946 x+0.0097$ and $r^{2}=$ 0.9613. As shown in Table 2, the content of total phenol compounds measured by the Folin-Ciocalteu method varied significantly $(\mathrm{p}<0.05)$ between propolis samples of the two locations.

The evaluation of the total antioxidant activity of propolis extracts collected in both locations and the rutin and ascorbic acid positive controls, in the concentrations of 50,100 and $200 \mu \mathrm{g} \mathrm{mL}$, are shown in Figure 1. Both geopropolis extract presented antioxidant activity statistically equal to the positive controls in the 100 $\mu \mathrm{g} \mathrm{mL} \mathrm{m}^{-1}$ and $200 \mu \mathrm{g} \mathrm{mL}^{-1}$ concentrations, achieving a maximum of $95.38 \pm 0.31 \%$ for $M$. scutellaris extract. A lower antioxidant activity was observed in the A. mellifera propolis extract collected in the city of Novo Acordo.

The $\mathrm{CE}_{50}$ DPPH analysis (Table 2) also showed that propolis extracts from both locations presented significant differences in their potential as sources of free radicals sequestrant substances. Values lower than the $\mathrm{CE}_{50}$ reflect a higher antioxidant activity, which was detected in both geopropolis extracts, which were very close to the ascorbic acid and rutin standards. This activity turned out to be very well correlated to total phenol concentrations $(-0.8042$, $\mathrm{p}$ $=0.1957)$ measured by the Pearson coefficient correlation.

Table 1. Physicochemical requirements from propolis samples from Tocantins and limits established by the Ministry of Agriculture, Livestock and Supply (MAPA).

\begin{tabular}{cccc}
\hline Sample & Loss by desiccation at $105{ }^{\circ} \mathrm{C}\left(\% \mathrm{~m} \mathrm{~m}^{-1}\right)^{\star}$ & Ashes $\left(\% \mathrm{~m} \mathrm{~m}^{-1}\right)^{*}$ & Wax $\left.(\% \mathrm{~m} \mathrm{~m})^{-1}\right)^{*}$ \\
\hline A. mellifera NA & $6.97 \pm 0.26$ & $2.92 \pm 0.05$ & $25.45 \pm 4.16$ \\
M. scutellaris NA & $2.94 \pm 0.30$ & $1.76 \pm 0.02$ & $24.09 \pm 4.22$ \\
A. mellifera SM & $3.30 \pm 0.08$ & $2.47 \pm 0.06$ & $0.95 \pm 0.91$ \\
M. fasciculata SM & $3.11 \pm 0.03$ & $1.40 \pm 0.04$ & Maximum 25\% \\
\hline Requirements in Legislation & Maximum $8 \%$ & Maximum $5 \%$ & \\
\hline
\end{tabular}

*Results presented in average \pm standard deviation. NA (Novo Acordo); SM (Santa Maria).

Table 2. Average and standard deviation values of antioxidant activity (DPPH CE ${ }_{50}$ in $\mu \mathrm{g} \mathrm{mL}^{-1}$ and total phenol concentrations (mg GAE g-1) found in four propolis samples collected in the cities of Novo Acordo (NA) and Santa Maria of Tocantins (SM).

\begin{tabular}{ccc}
\hline Propolis Sample & $\mathrm{DPPH}\left(\mathrm{CE}_{50} \mu \mathrm{g} \mathrm{mL}^{-1}\right)$ & Total phenol $\left(\mathrm{mg} \mathrm{GAE} \mathrm{g}^{-1}\right)$ \\
\hline M. scutellaris NA & $50.23 \pm 1.60 \mathrm{c}$ & $620.01 \pm 6.45 \mathrm{a}$ \\
A. mellifera SM & $260.34 \pm 12.27 \mathrm{~b}$ & $150.78 \pm 0.610 \mathrm{~b}$ \\
M. fasciculata SM & $29.81 \pm 2.49 \mathrm{c}$ & $631.29 \pm 4.22 \mathrm{c}$ \\
A. mellifera NA & $845.38 \pm 31.60 \mathrm{a}$ & $121.53 \pm 3.05 \mathrm{~d}$ \\
Rutin & $53.29 \pm 4.10 \mathrm{C}$ & - \\
Ascorbic Acid & $19.20 \pm 2.53 \mathrm{c}$ & - \\
\hline
\end{tabular}

Averages followed by the same letter do not differ statistically between each other at the level of $5 \%$ significance by Tukey test. 


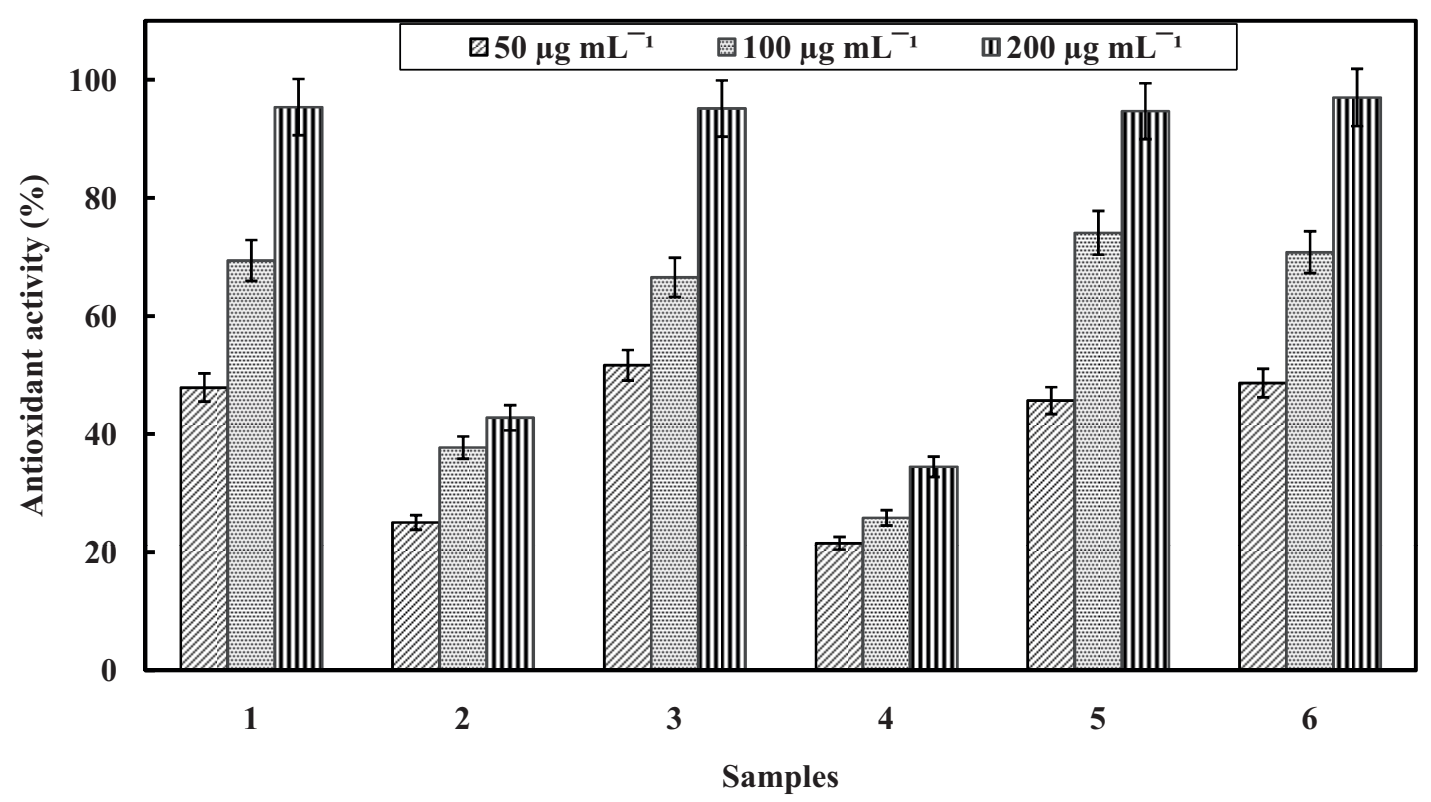

Figure 1. Percentage of antioxidant activity of ethanol extract from propolis samples collected in the cities of Novo Acordo (NA) and Santa Maria of Tocantins (SM) and from positive controls in three concentrations (50, 100 and $\left.200 \mu \mathrm{g} \mathrm{mL}^{-1}\right) .1-$ M. scutellaris NA, $2-A$. mellifera SM, $3-$ M. fasciculata SM, $4-A$. mellifera NA, 5 - rutin positive control and 6 - ascorbic acid positive control. The bars indicate the standard errors.

The evaluation by preparative thin layer chromatography - TLC showed, in all propolis extracts, the existence of phenol compounds, mainly flavonoids, as evidenced by the development of fluorescence in $\mathrm{R}_{\mathrm{f}}$ stains, which is characteristic for reference standards.

The fingerprinting of propolis samples obtained by HPLC are presented in Figure 2. The comparison of the retention time of samples and the authentic standards allowed the identification of various phenol compounds, such as: ellagic acid (time 29.687 min.), gallic acid (time $8.504 \mathrm{~min}$.), catechin (time 12.596 min.), gallocatechin (time $9.774 \mathrm{~min}$.), hesperidin (time 27.873 min.), kaempferol (time 30.393 min.), luteolin (time 31.487 min.), morin (time $28.889 \mathrm{~min}$.), naringin (time $28.419 \mathrm{~min}$.), naringenin (period $30.7652 \mathrm{~min}$.) and rutin (time $28.618 \mathrm{~min}$.). The detection of these substances in extracts are shown in Table 3.

\section{DISCUSSION}

The physical aspects of propolis observed in this study, sandy and resinous, are coherent with the Kerr data (1996), where different forms of propolis production were observed between Meliponinae and A. mellifera bees. Dutra et al. (2008) found that Meliponinae add clay or soil to the resinous material collected, forming geopropolis, differently from propolis produced by $A$. mellifera. In terms of chemical composition, the products produced by native bee (Meliponinae) are less known when compared with the ones produced by $A$. mellifera bees (Evangelista-Rodrigues et al. 2005).
Propolis obtained from the A. mellifera has a higher concentration of moisture when compared to propolis from Meliponinae. The moisture concentrations suggest that propolis produced by $A$. mellifera bees has a chemical composition capable of retaining a higher quantity of water. The moisture concentration results demonstrated that the propolis analyzed are in accordance to the values preconized by current legislation, where it is established that gross propolis must have a maximum moisture concentration of $8 \%\left(\mathrm{~m} \mathrm{~m}^{-1}\right)$ (BRAZIL 2001).

The ash results found are within the maximum limit of 5\%, established by specific legislation (BRAZIL 2001). The result was consistent with the data obtained in the ash concentration analyzes conducted by Longhini et al. (2007).

The wax concentration is in accordance to the legislation requirements, which is $25 \%$ of wax. However, considered high levels when compared to the results obtained by Rodríguez et al. (2012). Propolis is a complex mixture containing resin, balm and wax, besides other components. Since phenol compounds are not present in wax, their quantification in the sample becomes an important parameter. In this way, it is desirable to achieve a lower wax concentration in the sample. The results showed that propolis produced by Meliponinae bees presented a lower wax concentration (\%) due to the presence of clay and soil in their composition.

Castro et al. (2007) found total phenol compound values in propolis produced by $A$. mellifera bees similar to the values 

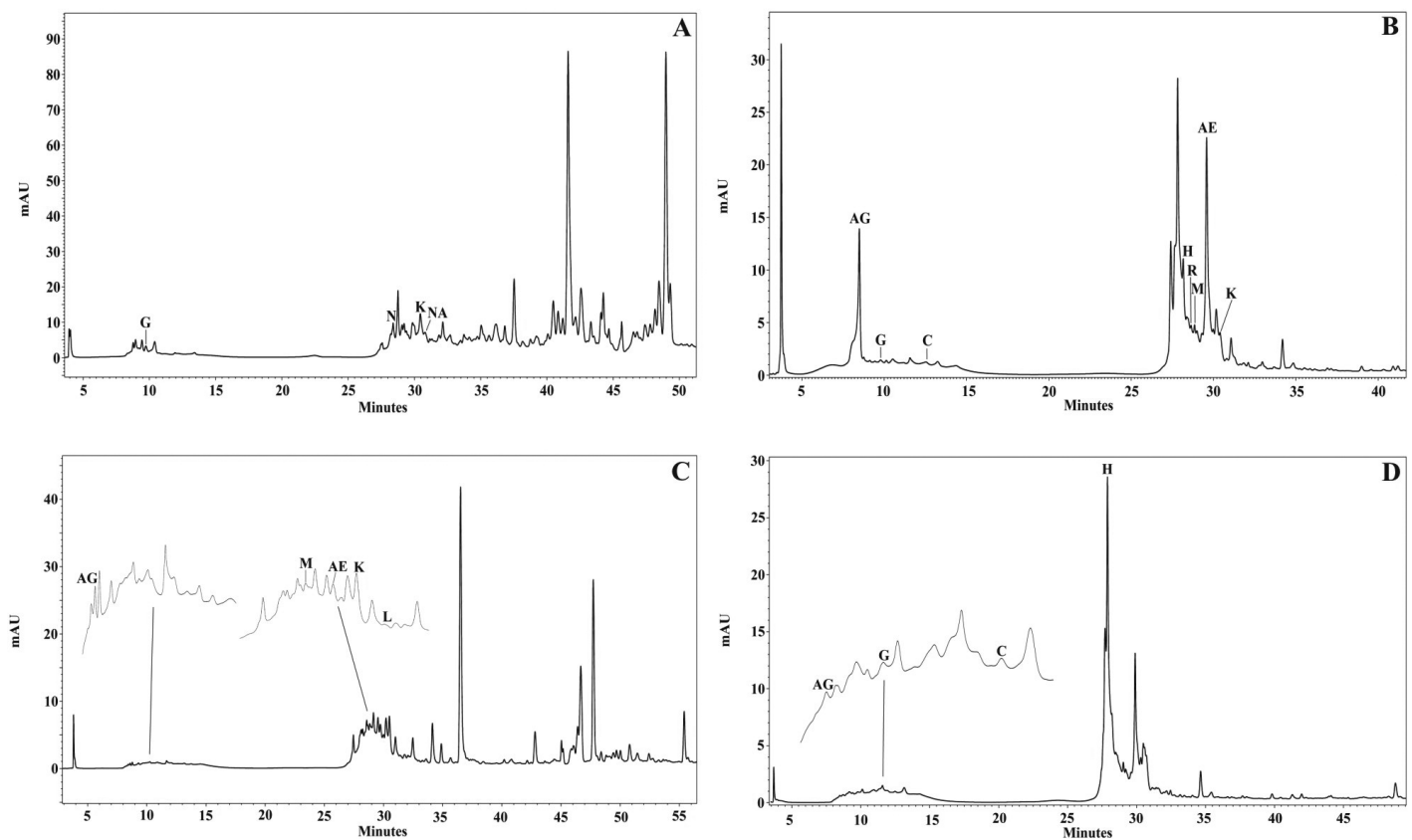

Figure 2. HPLC fingerprinting of ethanol extract from propolis samples collected in the cities of Novo Acordo and Santa Maria of Tocantins. A. A. mellifera - City of Novo Acordo; B. M. scutelaris - City of Novo Acordo; C. A. mellifera - City of Santa Maria; D. M. fasciculata - City of Santa Maria. (EA) ellagic acid, (GA) gallic acid, $(C)$ catequin, $(G)$ galocatequin, $(H)$ hesperidin, $(K)$ kaempferol, $(L)$ luteolin, $(M)$ morin, $(N)$ naringin, (NA) naringenin, $(R)$ rutin.

Table 3. Phenol compounds identified by HPLC in the propolis sample extracts produced by native atrophied sting bees and Africanized bees from the region of Novo Acordo and Santa Maria of Tocantins.

\begin{tabular}{ccccc}
\hline & \multicolumn{2}{c}{ Novo Acordo } & \multicolumn{2}{c}{ Santa Maria } \\
\cline { 2 - 5 } Phenol Compounds & A. mellifera & M. scutellaris & mellifera & M. fasciculata \\
\cline { 2 - 5 } & EtOH & EtOH & EtOH & EtOH \\
\hline Ellagic acid & - & + & + & - \\
Galic acid & - & + & - & + \\
Catequin & - & + & - & + \\
Galocatequin & + & + & + & + \\
Hesperidin & - & + & + & - \\
Kaempferol & + & - & + & - \\
Luteolin & - & + & - & - \\
Morin & - & - & - & - \\
Naringin & + & - & - & - \\
Naringenin & + & + & - \\
Rutin & - & & & + \\
\hline
\end{tabular}

(+) compound detected in the extract; (-) not detected.

found in propolis produced by $A$. mellifera bees from the city of Santa Maria of Tocantins. However, Rodríguez et al. (2012) and Cottica et al. (2011) found higher values for propolis produced by this species. No studies were found showing total phenol concentrations as high as that from the propolis produced by M. fasciculata - city of Santa Maria.
The difference between the total phenol concentrations from these bees constitutes a differential characteristic of this species, which can be associated to the production of geopropolis by Meliponinae and propolis with resin by $A$. mellifera.

This difference between total phenol concentrations and antioxidant activity, found in this study, can be related to 
the high wax concentration, typical in propolis produced by $A$. mellifera, which presented a lower phenol constitution and free radical sequestrant substances. Because, according to Rodríguez et al. (2012), the quantity of wax is a major influencing factor in phenol content of bee products.

Significant amounts of total phenol, obtained in this study, with both Melliponas bees corroborate data obtained by Silva et al. (2013), indicating that it is characteristic for this type of bee the collection of a major quantity of phenol compounds, since these authors studied two different species for the same genre.

The influence of the extract concentration over the development of antioxidant activity may be related to the high concentrations of phenol compounds present in the propolis samples (Lima et al. 2009), since these compounds have a major influence in the biological role. This is confirmed by the high correlation observed between total phenol concentrations and antioxidant activity. Palomino et al. (2009) elaborated a correlation and identified that around $60 \%$ of the antioxidant activity of evaluated propolis resulted from the contribution of phenol compounds.

The presence of phenol compounds detected in the preparative chromatography analysis TLC and the quantifications in spectrophotometry of propolis samples were confirmed by HPLC analysis, which allowed establishing particular characteristics for each extract. As observed in fingerprinting (Figure 2 and Table 3), flavonoid luteolin was restricted to the samples collected in Santa Maria of Tocantins, while, naringerin and rutin, were restricted to the samples collected in Novo Acordo, demonstrating substantial differences between bee pasture of the studied regions. At the same time, it was observed that gallic acid, catequin, galocatequin and kaempferol are fundamental compounds in the formation of propolis of these species, since they were present in most extracts (Cueto et al. 2011). It is important to notice that the diversity of compounds observed is consistent with data from literature (Maróstica Jr et al. 2008; Cueto et al. 2011; Morlock et al. 2014). The identified compounds are described as important in the defense to oxidative damage of biological molecules and able to aid in the treatment of various pathologies (Tao et al. 2014).

\section{CONCLUSION}

Propolis samples collected in the two regions of Tocantins presented concentrations of moisture, ash and wax that fall under Brazilian legislation for propolis quality. They also evidence a high concentration of phenol compounds and good antioxidant capacity. The variety of phenol compounds identified in propolis samples collected for this study, compared to the diverse biological functions described in literature for these compounds, indicates that there is a great pharmacological potential in this raw material.

\section{ACKNOWLEDGEMENTS}

The authors acknowledge the Federal University of Tocantins for the logistic support. This research was partially supported by the 'Núcleo de Estudos em Doenças Negligenciadas: Rede Tocantinense de Diagnóstico, Prevenção e Controle', SECT/CNPq 016/2011.

\section{REFERENCES}

Alencar, S.M.; Aguiar, C.L.; Guzmán, J.P.; Park, Y.K. 2005. Composição química de Baccharis dracunculifolia. Ciência Rural, 35: 909-915.

Amorim, E.L.C.; Nascimento, J.E.; Monteiro, J.M.; PeixotoSobrinho, T.J.S.; Araújo, T.A.S.; Albuquerque, U.P. 2008. A simple and accurate procedure for the determination of tannin and flavonoid levels and some applications in ethnobotany and ethnopharmacology. Functional Ecosystems and Communities, 2: 88-94

AOAC International. 2005. Association of Official Analytical Chemists. $18^{\text {th }}$ ed. AOAC International, Gaithrsburg, 2005, 858p.

BRASIL. 2001. Ministério da Agricultura, Pecuária e Abastecimento (MAPA). Instrução Normativa no 3, de 19 de janeiro de 2001. Aprova os Regulamentos Técnicos de Identidade e Qualidade de Apitoxina, Cera de Abelha, Geléia Real, Geléia Real Liofilizada, Pólen Apícola, Própolis e Extrato de Própolis. Diário Oficial [da]República Federativa do Brasil. Brasília, DF, 23 jan 2001. Seção 1, p. 18-23.

Cabral, I.S.R.; Oldoni, T.L.C.; Alencar, S.M.; Rosalen, P.L.; Ikegaki, M. 2012. The correlation between the phenol composition and biological activities of two varieties of Brazilian propolis (G6 and G12). Brazilian Journal of Pharmaceutical Sciences, 48: 557-564.

Castro, M.L.; Cury, J.A.; Rosalen, P.L. 2007. Própolis do sudeste e nordeste do Brasil: influência da sazonalidade na atividade antibacteriana e composição fenólica. Quimica. Nova, 30: 1512-1516.

Cottica, S.M.; Sawaya, A.C.H.F.; Eberlin, M.N.; Franco, S.L.; Zeoulae, L.M.; Visentainera, J.V. 2011. Antioxidant activity and composition of propolis obtained by different methods of extraction. Journal of the Brazilian Chemical Society, 22: 929-935.

Cueto, A.P.; Alves, S.H.; Weiblen, M.P.R. Kubiça, T.F. Lovato, L.T. 2011. Atividade antiviral do extrato de própolis contra o calicivírus felino, adenovírus canino 2 e vírus da diarréia viral bovina. Ciência Rural, 41: 1800-1806.

Dutra R.P.; Nogueira A.M.C.; Marques R.R.O.; Costa M.C.P.; Ribeiro M.N.S. 2008. Avaliação farmacognóstica de geoprópolis de Melipona fasciculata Smith da Baixada maranhense, Brasil. Brazilian Journal of Pharmacognosy, 18: 557-562.

European pharmacopoeia. 2002. $4^{\text {th }}$ ed. Strasbourg, Council of Europe, $1234 \mathrm{p}$.

Evangelista-Rodrigues, A.; Silva, E.M.S.; Beserra, E.M.F.; Rodrigues, M.L. 2005. Análise físico-química dos méis das abelhas Apis mellifera e Melipona scutellaris produzidos em regióes distintas no Estado da Paraíba. Ciência Rural, 35: 1166-1171. 
Figueiredo Filho, D.B.; Silva Júnior, J.A. 2009. Desvendando os Mistérios do Coeficiente de Correlaçáo de Pearson (r). Revista Política Hoje, 18: 115-146.

Franchin, M.; Cunha, M.G.; Denny, C.; Napimoga, M.H.; Cunha, T.M.; Bueno-Silva, B.; et al. 2013. Bioactive Fraction of Geopropolis from Melipona scutellaris Decreases Neutrophils Migration in the Inflammatory Process: Involvement of Nitric Oxide Pathway. Evidence-Based Complementary and Alternative Medicine. 2013: 1-9.

Kerr, W.E.; Carvalho, G.A.; Nascimento, A. 1996. Abelha Uruçu: Biologia, Manejo e Conservação. Acangaú, Belo Horizonte, Minas Gerais, 1996, 144 p.

Lima, B.; Tapia, A.; Luna, L.; Fabani, M.P.; Schmeda-Hirschmann, G.; Podio, N.S.; Wunderlin, D.A.; Feresin, G.E. 2009. Main flavonoids, DPPH activity, and metal content allow determination of the geographical origin of propolis from the province of San Juan (Argentina). Journal of Agricultural and Food Chemistry, 57:2691-2698.

Longhini, R; Raksa, S.M.; Oliveira, A.C.P.; Svidzinski, T.I.E.; Franco, S.L. 2007. Obtençáo de extratos de própolis sob diferentes condiçôes e avaliação de sua atividade antifúngica. Revista Brasileira de Farmacognosia, 17: 388-395.

Maróstica Jr, M.R.; Daugsch, A.; Moraes, C.S.; Queiroga, C.L.; Pastore, G.M.; Parki, Y.K. 2008. Comparison of volatile and polyphenolic compounds in Brazilian green propolis and its botanical origin Baccharis dracunculifolia. Ciência e Tecnologia de Alimentos, 28: 178-181.

Marquele, F.D.; Oliveira, A.R.M.; Bonato, P.S.; Lara, M.G.; Fonseca, M.J.V. 2006. Propolis extract release evaluation from topical formulations by chemilumine scence and HPLC. Journal of Pharmaceutical and Biomedical Analysis, 41: 461-468.

Morlock, G.E.; Ristivojevic, P.; Chernetsova, E.S. 2014. Combined multivariate data analysis of high-performance thin-layer chromatography fingerprints and direct analysis in real time mass spectra for profiling of natural products like propolis. Journal of Chromatography A, 1328:104-12.

Palomino G., L.R.; García P., C.M.; Gil, G.J.H.; Rojano, B.A., Durango R., D.L. 2009. Determinación del contenido de fenoles y evaluación de la actividad antioxidante de propóleos recolectados en el departamento de Antioquia (Colombia). Vitae, Revista De la Facultad de Quimica Farmacéutica, 16: 388-395.

Park, Y.K.; Ikegaki, M.; Abreu, J.A.S.; Alcici, N.M. 1998. Estudo da preparação dos extratos de própolis e suas aplicaçóes. Food Science and Technology. 18: 313-318.
Peixoto-Sobrinho, T.J.S.; Castro, V.T.N.A.; Saraiva, A.M.; Almeida, D.M.; Tavares, E.A.; Amorim, E.L.C. 2011. Phenol content and antioxidant capacity of four Cnidoscolus species (Euphorbiaceae) used as ethnopharmacologicals in Caatinga, Brazil. African Journal of Pharmacy and Pharmacology. 5: 2310- 2316.

Perchyonok, V.T.; Zhang, S.; Grobler, S.R., Oberholzer, T.G. 2013. Insights into and relative effect of chitosan- $H$, chitosan $-\mathrm{H}^{-}$propolis, chitosan- ${ }^{-} \mathrm{H}^{-}$propolis ${ }^{-}$nystatin and chitosan $-\mathrm{H}^{-}$nystatin on dentine bond strength. European Journal of Dentistry, 7: 412-418.

Prado, A. 2009. Composição fenólica e atividade antioxidante de frutas tropicais. Dissertação de mestrado. Escola Superior de Agricultura Luiz de Queiroz, Universidade de São Paulo, Piracicaba, São Paulo. 107p.

Restivo, A.; Degano, I.; Ribechini, E.; Colombini, M.P. 2014. Development and optimisation of an HPLC-DAD-ESI-Q- To $F$ method for the determination of phenol acids and derivatives. PLOS ONE, 9: e88762.

Rodríguez, Y.; Sánchez-Catalán, F.; Rojano, B.; Durango, D.; Gil, J.; Marín-Loaiza, J. 2012. Caracterización fisicoquímica y evaluación de la actividad antioxidante de propóleos recolectados en el departamento del Atlántico, Colombia. Revista Universidad de Ciencias Aplicadas y Ambientales Actualidad Y Divulgación Cientifica, 15: 303-311.

Silva, E.C.C., Muniz, M.P., Nunomura, R.C.S., Nunomura, S.M., Zilse, G.A.C. 2013. Constituintes fenólicos e atividade antioxidante da geoprópolis de duas espécies de abelhas sem ferrão amazônicas. Química Nova, 36: 628-633.

Simões, C.C.; Araújo, D.B.; Araújo, R.P.C. 2008. Estudo in vitro e ex vivo da ação de diferentes concentraçôes de extratos de própolis frente aos microrganismos presentes na saliva de humanos. Brazilian Journal of Pharmacognosy, 18: 84-89.

Sonmez, S.; Kirilmaz, L.; Yucesoy, M.; Yucel, B.; Ylmazb. 2005. The effect of bee propolis on oral pathogens and human gingival fibroblast. Journal of Ethnopharmacology, 102: 371-376.

Tao, Y.; Wang, D.; Hu, Y.; Huang, Y.; Yu, Y.; Wang, D. 2014. The immunological enhancement activity of propolis flavonoids liposome in vitro and in vivo. Evidence-Based Complementary and Alternative Medicine, 2014: 1-8.

Recebido em 23/03/2015

Aceito em 07/07/2015 